DOI: 10.20472/IAC.2019.048.018

SONGPORN HANSANTI

Faculty of Business Administration, Kasetsart University, Thailand

THANABADEE WAYUWATTANASIRI

Faculty of Business Administration, Kasetsart University, Thailand

DAOROONG AIYADECH

Faculty of Business Administration, Kasetsart University, Thailand

\title{
MARKETING FACTORS AND BRAND EQUITY IN ON THE CONSUMER'S BUYING DECISION OF MODERN TRADE THE DOHOME IN BANGKOK AND ITS VICINITY.
}

\begin{abstract}
:
The objectives of this research were to study the marketing factors and brand equity influence on the buying decision of modern trade Dohome in Bangkok and its vicinity. The samples for the research were 385 people who purchased product in the modern trade Dohome in Bangkok. The questionnaires were used for the research tool, whereas the statistics used for analyzing the obtained data were percentage, frequency, mean, standard deviation and multiple regression analysis. The results showed that overall level of opinions on marketing factors and brand equity of modern trade Dohome is high level. Furthermore, overall level of purchasing decision is high level too. Results of the hypothesis test showed that marketing factors in product and price influences buying decisions and brand equity in perceived quality influences buying decisions of the modern trade Dohome with a statistical significance at a 0.05 level.
\end{abstract}

\section{Keywords:}

Marketing Factors, Brand Equity, Buying Decision

JEL Classification: M31, M30 